\title{
Representatives of Rosaceae Juss. in the various structure-functional types of decorative plantings of Kryvyi Rih city (Dnipropetrovsk region, Ukraine)
}

\author{
Y.S. Yukhimenko ${ }^{1,2, *}$, I.I. Korshykov ${ }^{1,2}$ \\ ${ }^{1}$ Kryvyi Rih Botanical Garden, National Academy of Sciences of Ukraine, Marshaka str. 50, 50089 Kryvyi Rih, Dnipropetrovsk region, \\ Ukraine; * yukhimenkoj@gmail.com \\ ${ }^{2}$ Donetsk Botanical Garden, National Academy of Sciences of Ukraine, Marshaka str. 16a, 50089 Kryvyi Rih, Dnipropetrovsk region, \\ Ukraine
}

Received: 30.03 .2020 | Accepted: 14.04 .2020 | Published: 30.06 .2020

\begin{abstract}
The objective of this study was to define the diversity of Rosaceae representatives in parks and squares of Kryvyi Rih city and to evaluate their vitality, longevity, and perspectives of a further application for landscaping of the region.

Material and methods. The object of our study were Rosaceae plantings in parks and garden squares of Kryvyi Rih. We used visual, morphometric, and statistical methods.

Results. In the parks and squares of Kryvyi Rih, family Rosaceae is the most diverse - it is represented by 43 species, five hybrids, and five cultivars, which together belong to 20 genera. The most represented genera are Spiraea (seven taxa), Sorbus (five), Cotoneaster (four), Malus (four), Padus (four), and Prunus (four), while the rest of genera comprises from one to three taxa. The geographic analysis suggests a significant prevalence of species from East-Asian (36.5\%) and Circumboreal (34.6\%) regions. According to the distribution of life forms, there is some predominance of shrubs; they represent $56 \%$ of the total number of Rosaceae. With regard to height classes, trees of the third class of size (34.6\%) and undersized shrubs (25\%) prevail. As for age structure, $20-40$-year-old shrubs and trees (about $70 \%$ ) predominate. The highest level of the vital state is noted for $60 \%$ of plants of this family, the average level - for $30 \%$, and low level - for $10 \% .72 \%$ of evaluated plants were classified as highly decorative and $28 \%$ as decorative. In the future, enrichment of plantings of the region may be carried out by using the collection stock of arboreal plants of Kryvyi Rih Botanical Garden of the NAS of Ukraine, comprising about 350 species, varieties, and cultivars of 31 genera of the family Rosaceae.
\end{abstract}

Conclusions. Most of the investigated Rosaceae plants, in conditions of a large industrial city located in the Steppe zone of Ukraine, were characterized by high viability and decorativeness. Hence, these plants deserve to be more widely used for the greening of cities and towns of the Right-Bank of the Steppe zone of Ukraine.

Keywords: Rosaceae, species distribution, taxonomical composition, age structure, decorativeness, vitality

\section{Introduction}

The problem of conservation and enrichment of plant resources is especially actual for arid industrialized regions. The district of
Kryvyi Rih has very complicated ecological conditions, which had arisen under enormous technogenic pressure amplified by the dry climate. Artificial plantings, in particular 
parks and squares, are the local centers of phytodiversity, which play an essential role in the optimization of urban areas. Investigations on taxonomic structure and vitality of such plantings are crucial for the development of the strategy of their conservation and improvement.

Following the scheme of agroclimatic division, Kryvyi Rih district belongs to the continental temperate sub-boreal semiarid climatic subzone. The main features of this subzone are: hot and dry summer; a quite cold winter, very often without snow; short spring; frequent droughts, and dry winds (Diachuk al., 2003).

Many plantings of the different functional roles were created in Kryvyi Rih city in the 1920s. Today the total area of parks in Kryvyi Rih is about 334 ha and garden squares - about 155 ha. These plantings mostly represented by the family Rosaceae Juss., which comprises 52 taxa, or $26.0 \%$ from a total number of arboreal taxa of the parks and squares in the region. Rosaceae, together with Oleaceae Hoffmans, Salicaceae Mirb. and Cupressaceae Gray also dominate in other regions of Ukraine (Kokhno et al., 1980, 1983; Kramarets et al., 1992). For example, Rosaceae represents $24.7 \%$ of taxonomic diversity of cultural flora in Henichesk city (Maltseva, 2016), from 14.8 to $17.5 \%$ - in Kherson city (Zahorulko, 2018), about 29.0\% - in Chernihiv city (Pototska, 2017), 22.5\% in Poltava city (Panasenko, 2007), and about $20.0 \%$ - in Khmelnytskyi city (Hanaba, 2016). In Volhynia, among the dominating genera are Cotoneaster Medik., Crataegus L., Spiraea L., and Malus Mill., which together comprise $10.2 \%$ of region's taxonomic diversity (Kotsun, 1999). In Ciscarpathia, genera Cotoneaster, Crataegus, Sorbus L., and Padus Mill. also widely represented, covering $18.4 \%$ of taxonomic diversity (Hniezdilova, 2003). In the industrial south-eastern region of Ukraine, Rosaceae represents about $37.0 \%$ from all urban plantings (Suslova etal., 2013), and consists of 27 taxa of trees and 24 taxa of shrubs. The most divers here are Malus (six species), Spiraea (four species and three cultivars), Cerasus Juss. (three species and two cultivars), Prunus L. (four species and two cultivars), Cotoneaster (three species and two cultivars), and Crataegus (three species) (Polyakov et al., 2015).
The first taxonomic survey of the parks in Kryvyi Rih was conducted in 1950-1960s by I.A. Dobrovolskiy, the professor of the Botany department of the Kryvyi Rih Pedagogical Institute (Dobrovolskiy, 1967). Among 40 dominating species distributed in parks and garden squares, he mentioned Padellus mahaleb (L.) Vassilcz. and Spiraea $\times$ vanhouttei (Briot.) Zabel. After that, the inventory of parks and garden squares in Kryvyi Rih was not conducted and becomes a necessary task for today.

This work aimed to revise the family Rosaceae in parks and squares of Kryvyi Rih city and to investigate vitality, longevity, and current decorativeness of its representatives. As well, to outline the perspectives of the application of Rosaceae representatives in the landscaping of the region.

\section{Material and methods}

Investigations were conducted in 23 parks and 93 garden squares located in seven districts of Kryvyi Rih city (Fig. 1). All these parks and squares officially belong to the Management of housing and communal services of the City Executive Committee.

Only in two parks and 17 garden squares, Rosaceae were not detected. In all other localities, surveys were conducted by the itinerary-visual method. The type of planting, the location, number, and age of individuals, as well as other parameters, were analyzed directly during the surveys. Identification of taxa was partly conducted directly in the field and partly - later, based on collected herbarium material with the use of identification guides (Kokhno et al., 2005). Taxa names are provided following ICN (2012) and IPNI (2013).

Vital condition of broad-leaved trees was evaluated following Saveleva's (1975) scale: 8 - the plant is robust, with intensive growth; 7 - the plant is robust, but growth is slowed down; 6 - apical growth is absent; 5 - accretion present only on lateral branches; 4 - accretion present only on lower lateral branches; 3 - accretion realized only by epicormic branches; 2 - only vegetative shoots are growing on the trunk, the crown of the tree shrinks out; 1 - only sprouts are present, the most of tree is dead; 0 - a tree is completely dead, including roots, any sprouts are absent. 


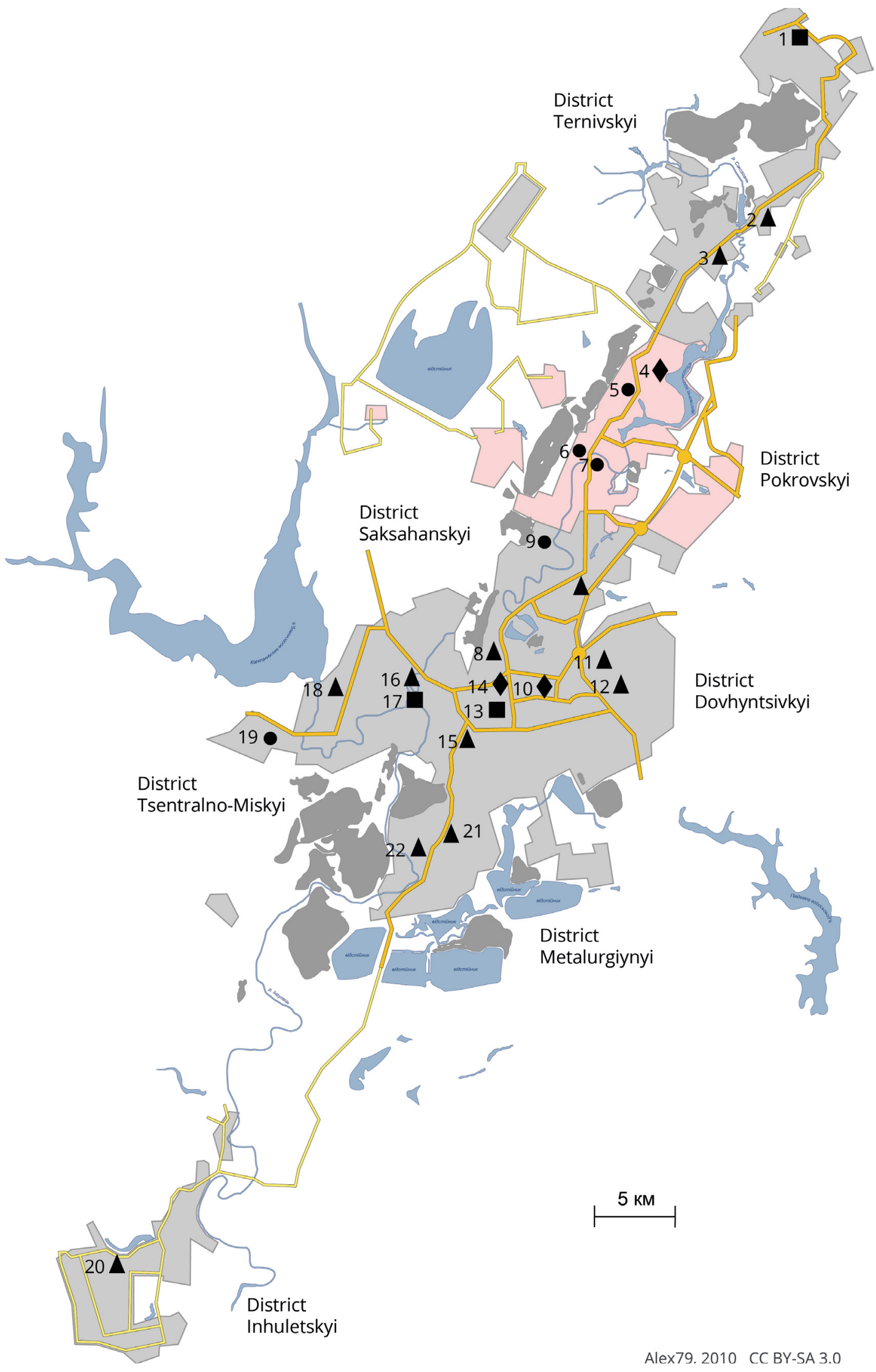

Figure 1. Administrative-territorial division of Kryvyi Rih city with locations of parks: 1 - Pivnichnyi; 2 - Veseli Terny; 3 - Ternivskyi; 4 - Shakhtarskyi; 5 - Dytiachyi; 6 - Park of Suvorov; 7 - Kosmonavtiv; 8 - Rudanivskyi; 9 - near Palace of culture of the mine "Rodina"; 10 - Yuvileinyi; 11 - Zaliznychnykiv; 12 - Druzhba; 13 - Park of Bohdan Khmelnytskyi; 14 - Heroyiv; 15 - Budivelnykiv; 16 - Park of Yurii Haharin; 17 - Park of Fedir Mershavtsev; 18 - Park of I. Pavlov; 19 - Park of O. Yehorov; 20 - Inhuletskyi; 21 - Yunatskyi; 22 - Park of I.I. Savytskyi. Number of taxa: - 11-30; $\boldsymbol{\Delta}$ - 31-50; - 51-70; - 71-90. 
Vital condition of broad-leaved shrubs was evaluated following the scale based on Luchnyk's (1988) classification: 1 - high, intensive growth of the plant, the number of new branches is higher than dead ones; 2 - moderate, the number of new branches is the same or slightly less than dead ones; 3 - a scanty, strong decrease of growth processes, the number of dead branches is higher that newly formed ones; 4 - low, shrub shrinks, new branches are few and weak if the plant has rhizome - the central part of such plant is dead and only low peripheral particles are alive; 5 - very low, the plant is completely dead.

The geographical analysis was realized in the context of the floristic regionalization of the Earth developed by Takhtajan (1978). Biomorphological study of cultivated flora was conducted following Serebryakov (1964). Plants were subdivided onto the classes by their height following Kolesnikov's (1974) scales for trees (I - $20 \mathrm{~m}$, II - 10-20 m, III - 5-10 m) and shrubs (I - 2-5 m, II - 1-2 m, III - 0.5-1 m). The plants also were subdivided by age classes, independent for trees (I - 0-20 years; II - 2140 years, III $-41-60$ years, IV - 61-80 years, $\mathrm{V}-81-100$ years) and shrubs (I - 0-10 years; II - 11-20 years, III - 21-30 years, IV - 31-40 years). The age of plants was established by indirect calculations, taking into account species, trunk diameter, the general condition of an individual plant, growing conditions, etc.

The occurrence coefficient was calculated as a relation of the number of areas with certain taxon to the total number of observed areas (parks and squares). Decorativeness was evaluated with the use of Vardanyan's (2017) modified scale, which is based initially on a comprehensive evaluation of the plant by nine criteria (with five points each) during the year and the following summation of resulting scores with winter hardiness grade. We substituted the winter hardiness for drought tolerance because it is more critical for dry conditions of the steppe zone. In turn, drought tolerance has been evaluated following modified scale of Pyatnitskiy (1961): 7 - plants without any evidence of drought influence, 6 - leaves loss turgor partly, 5 - leaves get partly damaged, obtain marginal necrosis, become brown and after that falling, 4 - leaves untimely obtain autumn coloration, 3 - young shouts death, 2 - the death of aboveground part of the plant, 1 - plant completely dead. Hence, by decorative value the plants were subdivided into classes: 1 - low decorativeness, plants received less than 25 points; 2 - moderate decorativeness, plants received $26-30$ points; 3 - high decorativeness, plants received 31-35 points; 4 - exceptional decorativeness, plants received over 35 points.

\section{Results and discussion}

The inventory of plantings of the parks and garden squares of Kryvyi Rih revealed that family Rosaceae is represented here by 43 species, five hybrids, and five cultivars, which belong to 20 genera. The most diverse is the genus Spiraea (seven taxa). The second place has genus Sorbus (five taxa), third place share genera Cotoneaster (four taxa), Malus (four taxa), Padus (four taxa), and Prunus (four taxa). The rest of Rosaceae genera are represented here only by one to three taxa. Together they represent five regions of the temperate zone of the world (Takhtajan, 1978). Taxa from EasternAsian (36.5\%) and Circumboreal regions $(34.6 \%)$ are predominating. Taxa from North American (13.5\%), Irano-Turanian (13.5\%), and Mediterranean (1.9\%) regions are weakly represented here.

The number of green areas, as well as the taxonomic diversity of Rosaceae growing there, differ dependently from the district of the city. In particular, in Ternivskyi district three parks of common use and two green areas of restricted access are located (the square of an industrial ground of the Northern Ore-Dressing and Processing Enterprise and the garden of the City Hospital Nr. 7), which comprises 30 species and one cultivar belonging to 18 genera of Rosaceae. In Pokrovskyi district there are located four parks and three garden squares with 11 species and one cultivar from the nine genera of Rosaceae. In Saksaganskyi district, there are two parks and 17 garden squares with 23 species and three cultivars from 16 genera of Rosaceae. In Dovhyntsivskyi district in three parks and 10 garden squares 19 species belonging to 14 genera of Rosaceae are distributed. Metalurgiynyi district has three parks and 26 garden squares with 26 species and three cultivars from 19 genera of the family. Tsentralno-Miskyi district has 
arboretum (former botanical garden of the Kryvyi Rih State University, which currently is a garden square), three parks, and seven garden squares, which together comprises 26 species and three cultivars belonging to 19 genera of the family. Finally, in Inhuletskyi district, there are two parks and 20 garden squares with 25 species and one cultivar belonging to 16 genera of Rosaceae.

In Kryvyi Rih, the cultivated dendroflora of parks and garden squares has a total of 202 species and cultivars belonging to 89 genera and 41 families (Terlyga et al., 2014). 16 species of Rosaceae were found the most used (with over 200 registered plants per each) in the landscaping of the city: Armeniaca vulgaris Lam., Cerasus avium (L.) Moench, C. tomentosa (Thunb.) Yas. Endo, Crataegus fallacina Klokov, Cydonia oblonga Mill., Malus domestica Borkh., Padus serotina Borkh., Physocarpus opulifolia Raf., Prunus divaricata Ledeb., P. pissardi Carrière, Pyrus communis L., Rosa canina L., Sorbus aucuparia L., Padus avium Mill., Padellus mahaleb, and Spiraea $\times$ vanhouttei (Table 1).

Thirteen Rosaceae taxa (about quarter) were found to be moderately represented in flora of parks and squares of Kryvyi Rih and comprise from 100 to 200 plants each: Amelanchier spicata K. Koch, Aronia melanocarpa (Michx.) Elliott, Cerasus vulgaris Mill., Chaenomeles maulei (Mast.) C.K. Schneid., Malus sylvestris (L.) Mill., Padus virginiana (L.) Mill., Physocarpus intermedia (Rydb.) C.K. Schneid., Prunus domestica L., P. domestica L. 'Wengerka', Rubus idaeus L., R. caesius L., Sorbus intermedia (Ehrh.) Pers., and Spiraea japonica Raf.

Other taxa, which are promising for landscaping, are quite rare in parks and garden squares of Kryvyi Rih and comprises less than 100 plants each: Amelanchier florida Lindl., Chaenomeles speciosa (Sweet) Nakai, Cotoneaster dammeri C.K. Schneid., C. lucidus Schlecht., C. procumbens G. Klotz., C. × suecica G. Klodz., Crataegus submollis Sarg., Kerria japonica (L.) DC. 'Pleniflora', Louiseania triloba (Lindl.) Pachom., L. ulmifolia (Franch.) Pachom., Malus baccata (L.) Borkh., M. prunifolia (Willd.) Borkh., Persica vulgaris Mill., Sorbus aucuparia L. 'Pendula', S. × thuringiaca (Nyman) Schönach, S. torminalis (L.) Crantz, Spiraea cantoniensis Lour., S. japonica 'Macrophylla', S. × bumalda Burv., S. × bumalda 'Goldflame', S. media F. Schmidt.
Among the life forms, shrubs are predominating by both occurrences and taxonomic diversity, representing $56.0 \%$ of the total number of Rosaceae taxa in parks and squares of Kryvyi Rih. The amount of lowgrowing shrubs is $25.0 \%$ (13 taxa), mediumsized shrubs - $19.3 \%$ (10 taxa), and high shrubs - $11.5 \%$. Trees are mostly represented by third class of height (18 taxa, 34.6\%), while trees of the second class of height are much less diverse (5 taxa, 9.6\%). In general, shrubs of IIIIV age class (21-40 years old) and trees of II age class (21-40 years old too) are more abundant, representing about $70.0 \%$ of the total number of investigated plants.

Observed trees are mostly single planted, rarely - they grow as small groups or solitaires (e.g., Pyrus communis). Solitaire of Sorbus $\times$ thuringiaca was found in the park Yunatskyi (Inhuletskyi district). Moved bordure $(0.5 \mathrm{~m}$ high) formed by Cydonia oblonga was located along the central lane in the square on Sedneva str. (Inhuletskyi district). Shrubs are mostly planted as small groups. Alley planting is represented only in the Park of Fedir Mershavtsev, where plants of Crataegus fallacina are shaped as single-trunk small trees. Plants of another species, Crataegus submollis, are formed as few-trunk small trees and used for solitaire in the park Yunatskyi.

Most parks and garden squares in Kryvyi Rih are located along the rivers Saksahan and Inhulets, i.e., in the best-watered places. However, some of the plantings are located far from natural water reservoirs and suffer from drought, dust, and gas pollution. This results in lower decorativeness and vitality of woody plants. Moreover, the condition of such plants also strictly depends on age, plantation density and solidity of crowns, and care works. Finally, the zonality of plantings also has a great influence on the growth of many species. In particular, a comparison of vitality parameters for plants from two remotely located districts, Ternivskiy in north and Inhuletskiy in the south, revealed that the in last district plants grow slowly with a weaker increase of height, have more dead branches, the irregular shape of crown, etc.

Analysis of vitality revealed that trees are more vulnerable, especially representatives of the genera Cerasus, Malus, Padus, Prunus, and Sorbus. Although most trees (about 70\%) have satisfactory vitality, many plants from 
Table 1. Rosaceae in plantings of parks and garden squares of Kryvyi Rih.

\begin{tabular}{|c|c|c|c|c|c|c|c|}
\hline \multirow[b]{2}{*}{ Taxa } & \multicolumn{2}{|c|}{$\begin{array}{c}\text { Occurrence } \\
\text { coefficient }\end{array}$} & \multirow[b]{2}{*}{$\begin{array}{l}0 \\
0 \\
\frac{\pi}{0} \\
0 \\
0 \\
0 \\
\end{array}$} & \multirow{2}{*}{ 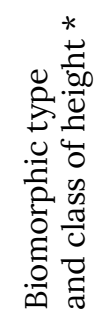 } & \multirow[b]{2}{*}{ 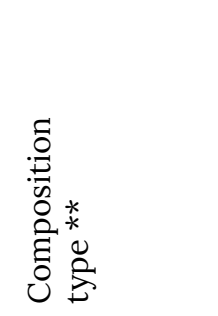 } & \multirow[b]{2}{*}{ 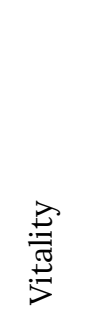 } & \multirow[b]{2}{*}{ 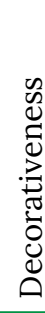 } \\
\hline & 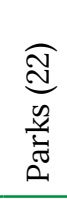 & 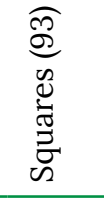 & & & & & \\
\hline Amelanchier florida Lindl. & 0 & 1 & III & $\mathrm{S}, \mathrm{I}$ & Gr. & 2 & 4 \\
\hline Amelanchier spicata K. Koch & 4 & 0 & III & $\mathrm{S}, \mathrm{I}$ & Gr. & 1 & 4 \\
\hline Armeniaca vulgaris Lam. & 54 & 25 & II, III & $\mathrm{T}, \mathrm{III}$ & Sing., Gr. & $6-8$ & 4 \\
\hline Aronia melanocarpa (Michx.) Elliott & 4 & 9 & II, III & $\mathrm{S}, \mathrm{I}$ & Gr. & $1-2$ & 4 \\
\hline Cerasus avium (L.) Moench & 23 & 4 & I, II & $\mathrm{T}, \mathrm{III}$ & Sing., Gr. & $6-8$ & 4 \\
\hline Cerasus tomentosa (Thunb.) Yas. Endo & 18 & 5 & II & $\mathrm{S}, \mathrm{III}$ & Gr. & $1-3$ & 4 \\
\hline Cerasus vulgaris Mill. & 9 & 7 & II, III & $\mathrm{T}, \mathrm{III}$ & Sing., Gr. & $7-8$ & 4 \\
\hline Chaenomeles japonica (Thunb.) Lindl. ex Spach & 14 & 6 & I-IV & $\mathrm{S}, \mathrm{III}$ & Gr. & $1-3$ & 4 \\
\hline Chaenomeles maulei (Mast.) C. K. Schneid. & 9 & 2 & I-IV & S, III & Gr. & 1 & 4 \\
\hline Chaenomeles speciosa (Sweet) Nakai & 0 & 1 & I-IV & S, III & Gr. & 1 & 4 \\
\hline Cotoneaster dammeri C.K. Schneid. & 0 & 1 & I & S, III & Gr. & 1 & 4 \\
\hline Cotoneaster lucidus Schlecht. & 4 & 0 & II, III & S, II & Gr. & $1-2$ & 4 \\
\hline Cotoneaster procumbens G. Klotz. & 0 & 2 & I & $\mathrm{S}, \mathrm{III}$ & Gr. & 1 & 4 \\
\hline Cotoneaster × suecica G. Klodz. & 0 & 1 & I & S, III & Gr. & 1 & 4 \\
\hline Crataegus fallacina Klokov & 46 & 3 & I-IV & $\mathrm{S}, \mathrm{I}$ & Sing., Gr., All. & I & 4 \\
\hline Crataegus submollis Sarg. & 4 & 0 & II & $\mathrm{S}, \mathrm{I}$ & Sol. & 1 & 4 \\
\hline Cydonia oblonga Mill. & 23 & 4 & II-IV & $\mathrm{T}, \mathrm{III}$ & Gr., Brd. & 8 & 4 \\
\hline Kerria japonica (L.) DC. 'Pleniflora' & 0 & 2 & II & $\mathrm{S}, \mathrm{III}$ & Gr. & 1 & 3 \\
\hline Louiseania triloba (Lindl.) Pachom. & 0 & 1 & II & $\mathrm{S}, \mathrm{III}$ & Gr. & 2 & 3 \\
\hline Louiseania ulmifolia (Franch.) Pachom. & 0 & 1 & II & S, II & Gr. & 1 & 3 \\
\hline Malus baccata (L.) Borkh. & 0 & 1 & III & $\mathrm{T}, \mathrm{III}$ & Sing. & 8 & 4 \\
\hline Malus domestica Borkh. & 45 & 12 & I-III & $\mathrm{T}, \mathrm{III}$ & Sing., Gr. & $5-8$ & 4 \\
\hline Malus prunifolia (Willd.) Borkh. & 0 & 1 & II & $\mathrm{T}, \mathrm{III}$ & Sing., Gr. & $5-7$ & 4 \\
\hline Malus sylvestris (L.) Mill. & 20 & 10 & II-III & $\mathrm{T}, \mathrm{III}$ & Sing. & $6-7$ & 4 \\
\hline Padus avium Mill. & 27 & 3 & III & $\mathrm{T}, \mathrm{II}$ & Sing., Gr. & $7-8$ & 3 \\
\hline Padus mahaleb Borkh. & 14 & 3 & II-IV & $\mathrm{T}, \mathrm{II}$ & Sing., Gr. & $7-8$ & 3 \\
\hline Padus serotina Borkh. & 18 & 7 & III & T, II & Sing., Gr. & $7-8$ & 3 \\
\hline Padus virginiana (L.) Mill. & 4 & 1 & III-IV & $\mathrm{T}, \mathrm{II}$ & Sing., Gr. & 8 & 4 \\
\hline Persica vulgaris Mill. & 0 & 2 & I-II & $\mathrm{T}, \mathrm{III}$ & Sing. & $7-8$ & 3 \\
\hline Physocarpus intermedia (Rydb.) C.K. Schneid. & 4 & 2 & III-IV & $\mathrm{S}, \mathrm{II}$ & Gr., Hdg. & $1-2$ & 3 \\
\hline Physocarpus opulifolia Raf. & 50 & 4 & III-IV & S, II & Gr., Hdg. & $1-2$ & 3 \\
\hline Prunus divaricata Ledeb. & 14 & 5 & I-III & $\mathrm{T}, \mathrm{III}$ & Sing. & $5-8$ & 4 \\
\hline
\end{tabular}

Note: * S - shrub; T - tree. ** Sing. - single planting; Gr. - group; All. - alley; Brd. - bordure; Hdg. - hedge; Sol. - solitaire. 
Table 1. Continued.

\begin{tabular}{|c|c|c|c|c|c|c|c|}
\hline \multirow[b]{2}{*}{ Taxa } & \multicolumn{2}{|c|}{$\begin{array}{c}\text { Occurrence } \\
\text { coefficient }\end{array}$} & \multirow[b]{2}{*}{$\begin{array}{l}0 \\
0 \\
0 \\
0 \\
0 \\
0 \\
\&\end{array}$} & \multirow{2}{*}{ 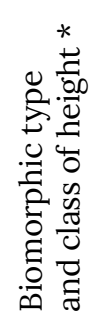 } & \multirow[b]{2}{*}{ 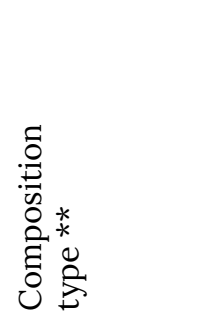 } & \multirow[b]{2}{*}{ 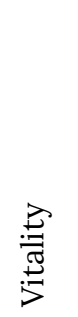 } & \multirow{2}{*}{ 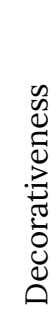 } \\
\hline & 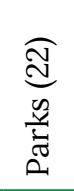 & 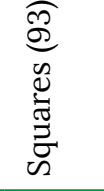 & & & & & \\
\hline Prunus domestica L. & 10 & 0 & II & T, III & Sing. & $5-8$ & 4 \\
\hline Prunus domestica L. 'Wengerka' & 45 & 9 & II & T, III & Sing., & 6 & 4 \\
\hline Prunus pissardi Carrière & 18 & 8 & I-III & T, III & Gr. & $4-8$ & 4 \\
\hline Pyracantha coccinea (L.) M. Roem. & 0 & 1 & I & S, II & Gr. & $1-2$ & 4 \\
\hline Pyrus communis L. & 45 & 11 & I-IV & T, II & Sol., Sing., Gr. & 8 & 3 \\
\hline Rosa canina L. & 64 & 31 & I-III & S, II & Sing., Gr. & 1 & 3 \\
\hline Rubus caesus L. & 4 & 0 & II-III & S, II & Sing. & 1 & 3 \\
\hline Rubus idaeus L. & 9 & 0 & II-III & S, II & Sing., Gr. & 1 & 3 \\
\hline Sorbus aucuparia L. & 68 & 39 & I-III & $\mathrm{T}, \mathrm{III}$ & Sing., Gr. & $6-7$ & 4 \\
\hline Sorbus aucuparia L. 'Pendula' & 0 & 1 & I & $\mathrm{T}, \mathrm{III}$ & Sing. & 8 & 4 \\
\hline Sorbus intermedia (Ehrh.) Pers. & 4 & 2 & II-III & $\mathrm{T}, \mathrm{III}$ & Gr. & 8 & 4 \\
\hline Sorbus $\times$ thuringiaca (Nyman) Schönach & 4 & 2 & II-III & $\mathrm{T}, \mathrm{III}$ & Gr. & 8 & 4 \\
\hline Sorbus torminalis (L.) Crantz & 4 & 0 & III & $\mathrm{T}, \mathrm{III}$ & Sol. & 8 & 4 \\
\hline Spiraea $\times$ bumalda Burv. & 4 & 0 & I-II & S, III & Gr. & 1 & 4 \\
\hline Spiraea × bumalda Burv. 'Goldflame' & 0 & 2 & I & S, III & Gr. & 1 & 4 \\
\hline Spiraea cantoniensis Lour. & 9 & 0 & II & S, II & Gr. & 1 & 4 \\
\hline Spiraea japonica Raf. & 4 & 2 & I-II & S, III & Gr. & 1 & 4 \\
\hline Spiraea japonica Raf. 'Macrophylla' & 9 & 2 & I-II & S, II & Gr. & 1 & 4 \\
\hline Spiraea media F. Schmidt & 4 & 0 & III-IV & S, III & Gr. & 1 & 3 \\
\hline Spiraea $x$ vanhouttei (Briot) Zabel & 41 & 44 & III-IV & $\mathrm{S}, \mathrm{I}$ & Gr. & 1 & 4 \\
\hline
\end{tabular}

Note: * S - shrub; T - tree. ** Sing. - single planting; Gr. - group; All. - alley; Brd. - bordure; Hdg. - hedge; Sol. - solitaire.

the plantings of Armeniaca vulgaris, Cerasus avium, Malus prunifolia, Prunus divaricata, P. domestica, and Sorbus aucuparia have 5-6 grades of vitality only. Shrubs appeared to be more labile to urban-technological environment conditions. They actively renew from underground buds if remove the dead branches. Hence, the vitality for the most shrubs was evaluated as high (first grade), and for the rest - as moderate (second grades).

About $60 \%$ of investigated plantings of Kryvyi Rih are left without care, and their distant parts look like dense tangles formed by self-sown plants, among which are Acer negundo L., A. platanoides L.,
Ailanthus altissima (Mill.) Swingle, Robinia pseudoacacia L., Ulmus pumila L., Morus nigra L., Fraxinus lanceolata Borkh. and other. Mass self-seeding also observed for some Rosaceae, including Crataegus fallacina and Padus mahaleb. Sometimes self-seeding also occurs in Cerasus vulgaris, C. avium, Prunus domestica, and Pyrus communis. Such uncontrolled self-recovering of woody vegetation can result in a complete change of species composition of these plantings because self-seeded and spear-originated ones will substitute artificially planted plants.

Trees and shrubs of Rosaceae are very decorative plants with numerous and 
attractive flowers, which can be both solitary or gathered in inflorescences. Usually, these plants have flowers of white or pink tints, and only Kerria japonica 'Pleniflora' has the yellow coloration of the perianth. The most representatives (38 taxa) of Rosaceae in Kryvyi Rih were evaluated as exceptionally decorative (4 grades), the rest - as highly decorative (3 grades).

Presence of some rare and unusual representatives of Rosaceae, which are perfectly adapted to the urban-technological environment of Kryviy Rih testify to the possibility of their future use in landscaping. For example, Chaenomeles speciosa, Cotoneaster divaricatus Rehd. et Wils., Padus serotina, Prunus pissardi, Sorbus aucuparia, and Spiraea × bumalda 'Goldflame' were successfully introduced in parks and squares during the last five years. However, the significant disadvantage is the low variation of newly created compositions and their greatly simplified structure (e.g., absence of accentcreating and nicely flowering plants). Regular care is realized only in few such plantings.

Parks and squares can be effectively enriched by Rosaceae from the collection of woody cultures of the Kryviy Rih Botanical Garden of the NAS of Ukraine. Today this collection hosts over 330 taxa from 31 genera of Rosaceae, which were tested during manyyears of introductive trial. Most of these taxa revealed to be drought-tolerant and suitable for growth in the condition of an industrial city. Amelanchier utahensis Koehne, Cerasus besseyi Smyth, Chaenomeles speciosa 'Brilliant', Cotoneaster gracilis Rehder et E.H. Wilson, C. $\times$ suecicus G. Klotz 'Coral Beauty', Crataegus microphylla K. Koch, Padus virginiana (L.) Mill., Pyrus salicifolia Pall., Physocarpus ribesifolius Komarov, Sorbaria sorbifolia (L.) A. Braun, Spiraea menziesii Hook., Spiraea prunifolia Siebold et Zacc. 'Plena' and some other taxa were found to be the most perspective for such purposes.

\section{Conclusions}

1. 43 species, five hybrids, and five cultivars were revealed in 23 parks and 93 garden squares of Kryviy Rih; this corresponds to $26.0 \%$ from the total amount of taxa represented there.
2. In two parks and 17 squares, representatives of Rosaceae were not found; this corresponds to $16 \%$.

3. Rosaceae in plantings of Kryviy Rih is mostly represented by trees of third height and low-growing shrubs, which were aged from 20 to 40 years and are tolerant to the conditions of this region.

4. The most diverse is genus Spiraea with seven taxa, second place belongs to genus Sorbus with five taxa. Plants from East-Asian (36.5\%) and Circumboreal (34.6\%) floristic regions predominate there.

5. Rosaceae trees are mostly planted as single plants, while shrubs - in groups.

6. The vitality of most examined woody plants is satisfactory and has been evaluated with 7-8 grades for trees (70\%) and 1-2 grades for shrubs (90\%).

7. Parks and garden squares can be enriched by plants of Rosaceae from the collection of woody cultures of the Kryviy Rih Botanical Garden of the NAS of Ukraine.

\section{References}

Diachuk, V. A., Babichenko, V. M. Bondarenko, Z. S., \& Rudishyna, S. F. (2003). Climate of Ukraine. Kyiv: Publishing House of Rayevskyi. (In Ukrainian)

Dobrovolskiy, I. A. (1967). Greening of Krvyi Rih Ore Basin. Bulletin of the Main Botanical Garden of the Academy of Sciences of USSR, 6, 42-46. (In Russian)

Hanaba, D. V. (2016). Taxonomical diversity of street dendroflora of the city of Khmelnytskyi. Scientific Notes of the Ternopil National Pedagogical University. Series Biology, 3-4(67), 25-30. (In Ukrainian)

Hniezdilova, V. I. (2003). Cultivated dendroflora of angiosperms of Ciscarpathia and perspectives of its use (Doctoral thesis). M. M. Gryshko National Botanical Garden of the NAS of Ukraine. (In Ukrainian)

ICN. (2012). International Code of Nomenclature for Algae, Fungi and Plants (Melbourne Code). Regnum Vegetabile, 154. Koeltz Scientific Books.

IPNI. (2013, March 3). International Plant Names Index. Retrieved from http://www.ipni.org/ index.html

Kohno, M. A,. Pasichniy, A. O., Chuprina, P. Ya., \& Tsykalyuk, G. P. (1980). Trees and shrubs of urban decorative plantings of Ciscarpathia and Transcarpathia. Ukrainian Botanical Journal, 37(2), 27-31. (In Ukrainian) 
Kohno, M. A., Kuznetsov, S. I., Doroshenko, O. K., Chuprina, P., \& Pasichniy, A. O. (1983). Dendroflora of cities of the south of Ukraine. Ukrainian Botanical Journal, 40(5), 12-14. (In Ukrainian)

Kokhno, M. A., Parkhomenko, L. I., Zarubenko, A. U., Vakhnovska, N. G., Horelov, O. M., Klymenko, S. V., Sobko, V. G., Shumyk, M. I., Doroshenko, O. K., Korshuk, T. G., Muzyka, G. I., Didenko, T. V., Horb, V. K., Kosenko, I. S., Kozlov, V. G., Kolesnichenko, O. M., Sydoruk, T. M., \& Kharchyshyn, V. T. (2005). Dendroflora of Ukraine. Wild and cultivated trees and shrubs. Angiosperms. Part II: Handbook. Kyiv: Phytosociocenter. (In Ukrainian)

Kolesnikov, A. I. (1974). Decorative dendrology. Moscow: Lesnaya promyshlennost. (In Russian)

Kotsun, L. O. (1999). Cultivated dendroflora of Volyn and perspectives of its use (Doctoral thesis). M. M. Gryshko National Botanical Garden of the NAS of Ukraine. (In Ukrainian)

Kramarets, V. O., Kucheriavyi, V. O., \& Solomakha, V. A. (1992). Park and forest-park vegetation of cities of the west of Ukraine. Ukrainian Botanical Journal, 49(3), 12-20. (In Ukrainian)

Luchnyk, Z. Y. (1988). Decorative longevity of shrubs in culture. Novosibirsk: Nauka. (In Russian)

Maltseva, S. Y. (2016). Dendroflora of Henichesk (Kherson Region, Ukraine). Bulletin of Kharkiv National Agrarian University. Series Biology, 2(38), 106-113. (In Ukrainian)

Panasenko, T. V. (2007). Dendroflora of parks of Poltava region: contemporary state, ways of conservation and development (Doctoral thesis). M. M. Gryshko National Botanical Garden of the NAS of Ukraine. (In Ukrainian)

Polyakov, A. K., Suslova, E. P., \& Harhota, L. V. (2015). Species of family Rosaceae Juss. in plantings of parks and squares of industrial cities of southwest of Ukraine. Scientific Bulletin of National University of Bioresources and Nature Management of Ukraine. Series Arboriculture and Ornamental Horticulture, 219, 247-255. (In Russian)
Pototska, S. O. (2017). Dendrological aspects of "conception of greening of city of Chernihiv". Bulletin of Ternopil National Pedagogical University. Series Biology, 2(69), 35-40. (In Ukrainian)

Pyatnitskiy, S. S. (1961). Practicum on forest selection. Moscow: Publishing House of Agrarian Literature. (In Russian)

Saveleva, L. S. (1975). Sustainability of trees and shrubs in protective plantings. Moscow: Lesnaya promyshlennost. (In Russian)

Serebryakov, I. G. (1964). Life forms of plants and studying of them. In Field geobotany. Vol. 3 (pp. 146-205.). Moscow - Leningrad: Nauka. (In Russian)

Suslova, O. P., Poliakov, O. K., \& Kharkhota, L. V. (2013). State of woody plants in park plantings of industrial cities of south-east of Ukraine. Industrial Botany, 13, 109-115. (In Ukrainian)

Takhtajan, A. L. (1978). Floristic regions of Earth. Leningrad: Nauka. (In Russian)

Terlyga, N. S., Fedorovskyi, V. D., Yukhymenko, Y. S., Danylchuk, A. V., Danylchuk, N. M., \& Lapteva, O. V. (2014). Botanical-geographical analysis and occurrence frequency of species of arboreal and fruticose vegetation of green plantings of Kryvyi Rih. Bulletin of Zaporizhzhya National University. Biological Sciences, 1, 200-210. (In Ukrainian)

Vardanyan, Z. A. (2017). Methodologic aspects of evaluation of decorativeness of tree plants. Reports of the National Academy of Sciences of Armenia, 117(4), 340-349. (In Russian)

Zahorulko, A. O. (2018). Taxonomical analysis and phytomonitoring of parks of Kherson city. Science and Education - a New Dimension. Natural and Technical Sciences, 6(17), 41-44. (In Ukrainian)

\title{
Представники родини Rosaceae Juss. у декоративних насадженнях різного структурно-функціонального типу у м. Кривий Ріг (Дніпропетровська обл.)
}

\author{
Ю.С. Юхименко ${ }^{1,2,}$ *, І.І. Коршиков ${ }^{1,2}$
}

\footnotetext{
1 Криворізький ботанічний сад НАН України, вул. Маршака, 50, м. Кривий Ріг, Дніпропетровська обл., 50089, Україна; * yukhimenkoj@gmail.com

2 Донецький ботанічний сад НАН України, вул. Маршака, 16а, м. Кривий Ріг, Дніпропетровська обл., 50089, Україна
} 
Мета - визначити різноманітність представників родини Rosaceae в парках та скверах м. Кривий Ріг, оцінити їхню життєздатність, довговічність, декоративність і перспективи подальшого використання в озелененні регіону.

Матеріал та методи. Об'єкт досліджень - насадження представників родини Rosaceae у парках та скверах м. Кривий Ріг. Методи досліджень - візуальні, морфометричні, статистичні.

Результати. У насадженнях парків та скверів м. Кривий Ріг родина Rosaceae $\epsilon$ найчисельнішою (представлена 43 видами, п'ятьма гібридами та п'ятьма культиварами, які належать до 20 родів). Перше місце за кількістю таксонів посідає рід Spiraea (сім), друге - Sorbus (п'ять), третє - роди Cotoneaster (чотири), Malus (чотири), Padus (чотири) і Prunus (чотири таксони). Решта родів презентовані однимтрьома таксонами. Географічний аналіз показав значне переважання видів із Східноазійської (36,5%) та Циркумбореальної (34,6\%) областей. Серед життєвих форм у таксономічному та кількісному відношенні дещо переважають чагарники, на частку яких припадає 56 \% від загальної кількості видів і культиварів. Переважають дерева третьої величини (34,6 \%) та низькорослі чагарники (25\%). Найбільшою є частка 20-40-річних чагарників і дерев (близько 70 \%). Найвищий рівень життєвого стану встановлено у $60 \%$ рослин, середній - у $30 \%$, низький - у $10 \%$. До високодекоративних рослин віднесено 72 \%, до декоративних - 28 \%. Оптимізація насаджень парків і скверів населених пунктів можлива за рахунок використання колекційного фонду деревних рослин Криворізького ботанічного саду НАН України, який налічує близько 350 видів, різновидів та культиварів із представників 31 роду родини Rosaceae.

Висновки. Більшість видів та культиварів родини Rosaceae в умовах великого промислового міста у степовій зоні України характеризуються високою життєздатністю та декоративністю. Ці рослини заслуговують на широке використання в озелененні населених пунктів Правобережного степового Придніпров'я. 